\title{
ESTUDO PARA UMA COMPOSIÇÃO: CIDADE E NARRATIVA
}

\section{Janaina Bechler ${ }^{1}$}

Esse artigo parte da reflexão de duas experiências que contam a cidade a partir dos seus limiares e apontam para a indissociabilidade da produção da narrativa de si e da produção da narrativa da cidade. A primeira delas é a produção de um livro ${ }^{2}$ de memória fotográfica de uma vila em processo de remoção na região do bairro Cristal, em Porto Alegre. A segunda, a produção de um vídeo-carta sobre Porto Alegre em companhia de um grupo de moradores das ruas da cidade ${ }^{3}$.

\begin{abstract}
Aqui não tinha nada quando vim pra cá, era mato, maricá. Na verdade os moradores mais antigos aqui sou eu, seu Paulino, a Clair, Zé Cascão, que morreu, seu Ildo, seu Zé. Sou de Santo Ângelo. Tem gente de todo lugar aqui, é uma imigração muito grande...Um dia fui no Big comprar o som e paguei em prestação. De tarde paguei a última e de noite veio o temporal e levou tudo, a casa toda. Seu Luiz queria se atirar atrás pra pegar o som. Foi tudo embora minhas coisas, depois me endireitei, graças a deus. Agora essa casinha aí ta louca pra cair de novo. Comprei essa maloca que vai lá na beirinha do valão, bem lá na beirinha. Lá é meu quarto... quer olhar?

(Lena, 2008)
\end{abstract}

Aquela cidade era janeiro, porto alegre, na zona sul. Estacionávamos o carro em uma grande avenida com pouco espaço para transitar em cima dos pés. No horizonte, automóveis, asfalto, terra revolta em obras, máquinas e homens na construção. A extensão se perdia na vista. Tudo era grande: a imensidão do rio/lago, os campos do prado, a extensão do que logo seria um Shopping. A estrada/avenida sem nenhum ônibus urbano até que fosse concluída a obra. Logo, avistávamos outra paisagem, colada na suntuosa e decadente imagem dos campos de andar a cavalo: a vila Foz Cavalhada, onde conheceríamos dona Lena e outros companheiros de morada e de luta.

Jurema foi quem nos levou a casa de Lena, que nos convidou a entrar. Um

\footnotetext{
${ }^{1}$ Universidade Federal do Rio Grande do Sul, Brasil.

2 O livro "Guardar na Memória - Imagens do Cristal" (2008) é um registro fotográfico (feito pela fotógrafa Fernanda Rechemberg)e de narrativas de moradores, de seis vilas situadas no bairro Cristal, que estavam em processo de remoção em função da construção de um shopping center. Esse bairro é paradigmático na cidade pelas mudanças características que vem sofrendo nos últimos anos. A proximidade com o Guaíba, com a zona sul da cidade e com o centro, o fazem querido pela especulação imobiliária. De um bairro muito residencial, com casas e práticas de vizinhança, onde se convivia, dentro do possível, com as diferenças sociais, está se tornando um bairro muito valorizado financeiramente e onde não há espaço para quem não pode pagar caro para morar.

3 Vídeo-carta "carta de Porto Alegre" feito em parceria com integrantes do Jornal Boca de Rua, entre 2003 e 2004. Foi endereçado para a Revista Ocas de São Paulo, vendida por moradores de rua, com a intenção de formar uma rede de correspondências entre cidades, olhadas pelos habitantes das ruas.
} 
gatinho malhado conduziu, com ela, para o quarto arejado que se abria em uma bela varanda. Lá cultivava qualidades variadas de plantas ornamentais e curativas. Era a beira do valão, cenário das enxurradas que levaram embora, de tempos em tempos, todas as coisas dos moradores. Lugar também muito poluído, não exatamente por dona Lena, mas pela cidade inteira que desemboca ali como plástico, na forma de refrigerante, cadeira, saco, isopor.

Lena, Olírio, Arnaldo, são pessoas que moram nas ruas irregulares da cidade, movendo-se entre ocupação e remoção.

\begin{abstract}
Na realidade eu não tive infância. Minha infância... não sei se foi muito triste ou muito feliz... sei que quando minha mãe me botava na creche eu chorava muito, eu não queria ficar na creche... eu pra mim, nos meus pensamentos, minha infância não foi muito boa... mas lembro que gostava muito de andar de ônibus... saía de casa, andava de ônibus, depois voltava... também brincava em praças (...) minha infância mesmo foi dormir na bat caverna...lá era um mocó... um buraco que tinha pra dentro da ponte... nós tinha assim de tudo....na rua nós tinha som, televisão, até geladeira nós tinha embaixo da ponte. Mas aí chegou a prefeitura e levou tudo embora...e fechou, colocou cimento pra nós não entrar mais... (Ceco, 2003)
\end{abstract}

Aquela cidade era fevereiro, Porto Alegre, avenida Rio Branco, próximo a rodoviária. No caminho até o ponto de pular a cerca de proteção, o contrafluxo dos automóveis e a ausência de cordão de calçada era um limiar da vida. Embaixo do viaduto, o barulho ensurdecia o calor do asfalto, num conflito aberto, onde não havia vencedor. Em frente, o horizonte depois do arame que separava o Guaíba do campo rizomático em que estávamos. E na parede, inscrições lembravam ocupações entusiasmadas. Ceco convidou a entrar nessa rua-não, nesse lado de dentro que é todo fora, cimentada a cavidade para não ser mais ocupada. Buscou mostrar os vestígios do seu período de ocupação em alguma marca do concreto e no traço invisível que a narrativa desenhou. Logo depois estacionou um carro e nos avisou que estávamos invadindo uma propriedade privada. Foi com arma apontada que deixamos aquele lugar de memória ilegítimo, inóspito, infantil, caverna, que organiza a história de Ceco e outros companheiros de vida.

Ceco, Joecir, André, Luiz moram nas ruas e fazem de lugares públicos casas de ocasião, as vezes por uma noite somente, caso não lhes seja permitida a permanência. Seu trabalho é, principalmente, fazer espaços. 
Caminhando com Ceco, André, Luiz, Joecir, Olírio, Lena, Arnaldo, tropecei em diversos trabalhos de memória da cidade. Ou melhor, diversos trabalhos de esquecimento da cidade. Ela não guardava vestígios das ocupações feitas por eles, e eles, muitas vezes, empenhavam-se em apagar da lembrança essas ocupações. Não é com lirismo que narram sua existência na cidade, ela varre pra lá e pra cá seus destinos para dar passagem a outras cristalizações de sentido. São "a vizinhança difícil", "o problema que deve ser considerado!", que estão no "lugar errado", que tem "uma vida errada". Também como pobre-coitados, desvalidos, os "sem". Muitas prefigurações que envolvem um cotidiano quando olhado de longe, lá de cima do asfalto, mas que explode caleidoscopicamente a cada aproximação. Variação, variação, vidas volantes ${ }^{4}$.

Essa existência movente, que é também uma característica preponderante no modo de vida contemporâneo ${ }^{5}$, coloca diversos problemas para quem decide contar uma história. Os próprios personagens tem dificuldade em fazer uma reunião de elementos, cada fragmento de história aparece tendo valor em si, sem dialogar com o seguinte e o anterior, fruto de algum evento, fora da sua capacidade de querer. Mesmo assim, continuamos querendo contar histórias, essas histórias, e talvez a vontade documentar nunca tenha experimentado a paixão que nossa época lhe reserva. Huyssen (2000) faz uma importante analogia entre a velocidade, o encurtamento de espaço-tempo de mudança no contemporâneo e uma reativa musealização da cultura, uma angústia de desaparecimento e então a necessidade de produzir memória, guardar. Na paisagem urbana contemporânea essa questão é evidente: a dicotomia entre a memória e o novo, como se a produção da memória fosse o esgotamento do tempo e como se a novidade existisse para se contrapor à lembrança.

O enlace cada vez mais seguro entre capital e estado impõe à cidade formas de existência marcadamente bárbaras, de ruínas sem história, do novo sem questão. A possibilidade dessa maneira de existir é o encurtamento do diálogo. Calando a narrativa dos contornos dos prédios, das margens dos rios, enquadrando a memória ${ }^{6}$, uma cidade

\footnotetext{
${ }^{4}$ Referência ao documentário "As Vilas Volantes: o verbo contra o vento", dirigido por Alexandre Veras, 2006. Através da palavra, habitantes de vilas obrigadas a se deslocar devido à ação das dunas e marés, reconstroem lugares, hábitos e práticas que não existem mais.

5 O ser humano contemporâneo, segundo Guattari (1992), é fundamentalmente desterritorializado. A subjetividade teria entrado no "reino do nomadismo generalizado", sem terra natal, sem ancestralidade. A cidade é o lócus desse movimento incessante, que se apresenta como paradoxo: ao mesmo tempo que tudo circula, tudo permanece. São os falsos movimentos, "em espaços padronizados, tudo se tornou cambiável e equivalente", cenários de paralisia da subjetividade.

${ }^{6}$ Pollak (1989) prefere usar, e pensamos ser interessante, o termo "memória enquadrada" para especificar melhor o sentido de memória coletiva, por ele carregar a dimensão de um "trabalho de enquadramento"
} 
se torna vendável. Vários problemas surgem desse emudecimento, principalmente para quem está na ponta menos valorizada dessa história, que acompanha de arrasto o fluxo das mudanças que os ventos progressistas impõe ao espaço. Um desses problemas é relativo a legitimidade do espaço do corpo, casa, acampamento, que é indissociável da história de vida e dos discursos sobre a cidade onde se está. As pré-figurações que decorrem dos enquadramentos de memória não somente legitimam a retirada abruta de pessoas, casas, animais, árvores de um lugar, mas tornam ilegítimas as histórias de vida que tem suporte naquele espaço.

A dialética lembrança/esquecimento se apoia basicamente na possibilidade de compartilhar experiências com outras pessoas, materializar o tempo em narrativas, contar para lembrar, contar para esquecer. Se a possibilidade de diálogo é negada, qual é a chance de fazer acontecer essa dialética?

As experiências de vida que passam ao largo do sentido dominante da cidade, do seu lado de fora, falam diretamente do vazio, do lugar onde a história de vida não encontra ponto de amarração no espaço e no tempo histórico e por isso evidenciam a costura, o avesso de um sistema.

A simbólica fronteira que separa meu corpo e o corpo da cidade foi ultrapassada e ao narrarem suas histórias de vida mostram que a separação é um artifício, é um efeito da própria narrativa. Separação fundamental de um tipo de subjetividade, que permite a criação de certa autonomia do caminhar em relação ao caminho, da casa em relação à rua, da vida que acontece do outro lado da parede do apartamento, que permite que diga: não sou, e daí afirmar um: eu sou, provisório, mutante, mas consistente.

Porém, algumas narrativas deixam passar o vazio, o vazio da malha que sustenta a separação, as fronteiras. E aí as histórias se confundem no véu, na própria malha porosa. A cidade e as histórias de vida contadas se misturam completamente, revelando o monumento histórico de uma praça como interlocutor, a beira do valão como motivo de mudança, o estatuto dos parques definindo um destino de moradia.

Tu vê, olha essa estátua, todo mundo vem pra chegar perto dela, dos nossos ancestrais que eu nem conheci fico pensando, ela calada encanta as pessoas, encanta a gente, a gente se sente bem aqui... quando vi isso, jana, eu me inspirei, fiquei emocionado, falando comigo mesmo, pô, eu quero crescer pra aprender a fazer alguma coisa dessas, eu quero não ser uma estátua, mas ter alguma coisa de lembrança pra deixar pro meu filho aprender comigo, esquecer o passado, só

ativo de memória de determinado grupo, que está sempre se processando. 
lembrar o presente porque o passado traz o presente pra frente... eu não vou ter uma estátua assim pra todo mundo dizer quem foi o A., mas vou deixar uma lembrança, uma imagem, uma poesia, qualquer coisa, para que um dia as pessoas lembrem da gente. (A., 2003)

Esse ensaio pretende fazer um pequeno percurso no conceito de narrativa e o lugar ocupado por ela na montagem subjetiva dos modos de contar e viver a cidade.

\title{
O lugar da Narrativa
}

\begin{abstract}
Eu tinha uns livros, que nem é daqui, mas falava de como é Porto Alegre. Eu que não sei ler... um guri leu pra mim e falou: Porto Alegre é muito legal. Pra ver que lá pra fora eles falam também daqui... e esse livro não é daqui: eu to te mostrando mas vou ler pra ti, começou a ler e falar um monte de coisas: aqui é a Usina do Gasômetro, e muito tempo atrás aqui na Alfândega não era chão, não era terra, era tudo rio, começou a falar um monte de coisas, que o Araújo Viana não era aqui era lá no centro... (A., 2003)
\end{abstract}

"Se contar uma história tem algum valor, de que ela serve?"

Com essa pergunta Jeanne Marie-Gagnebin percorre na história da filosofia conceitos de história e Narração. Quer pensar o núcleo narrativo comum à história como disciplina e à história como narração.

Jeanne Marie (2005) vai aos discursos de Heródoto e Tucídides, em busca de traçar uma descrição da constituição do discurso que depois se chamará história. Sua descrição começa pelos discursos de Heródoto. Carregados pela tradição da oralidade, falam daquilo que viu ou do que ouviu falar, privilegiando a palavra da testemunha, mencionando inúmeras vezes suas fontes.

A históriè de Heródoto possui significado bem distante do história, que ela originou. A palavra grega tinha um sentido muito mais amplo, aquele viu, testemunhou, conta aspectos que considera dignos de menção e memória. Enquanto a história constitui-se de objetividade e tem a intenção de ir longe no passado e perpetuar-se ao futuro, a históriè de Heródoto, "não pretende abarcar um passado distante. Tal restrição também a delimita em relação ao discurso mítico, que fala de um tempo longínquo, de um tempo das origens, tempo dos deuses e dos heróis, ao qual só as musas podem nos fazer lembrar, pois, sem elas, não podemos saber daquilo que não vimos" (Gagnebin, 2005: 15).

Em Tucídides a histórica contada aparece interpretada, descrita sem a pretensão de exatidão com o que foi visto, reproduz o passado de acordo com as conveniências em 
relação ao presente. Com isso, permite compreender racionalmente a história, mas impede que se conheça outra história que não seja a sua. Com ele, a história se engaja com outras exigências. Em Heródoto, remetia à tradição poético-literária das mythodes, e em Tucídides "às exigências político-jurídicas de um cidadão preocupado com o futuro". Gagnebin destaca que, com ele, "o 'historiador' abandona - por longo tempo a dimensão ficcional da história para consagrar-se à sua dimensão política, muitas vezes erigida como única e verdadeiramente histórica" (Gagnebin, 2005: 28).

Tucídides é compromissado com a objetividade, ter uma ideia clara dos eventos ocorridos, escreve no presente, sobre o presente, para instituir o futuro. Não tem a preocupação de 'salvar o passado" ou de contar o maravilhoso, mas em fazer uma penetração racional e analítica deste magma informe que são os fatos do passado, para deles extrair um ktéma eis aei, uma aquisição, um tesouro para sempre (Gagnebin, 2000: 28.)

Substitui a figura do historiador que lia o texto em voz alta ao público presente, pelo que escreve rigorosamente com vistas ao leitor a vir. Mas o faz a partir da teoria do poder e da dominação, sem distinguir a racionalidade da realidade histórica da razão dos vencedores.

$\mathrm{O}$ ato de narrar, na obra de Walter Benjamin, liga-se ao conceito antigo da històrié, vinculado às artes de contar dos viajantes e a tecitura das práticas artesanais. A narrativa é o lugar da transmissão de um "tesouro", um ensinamento, que o final de um percurso, confere. O moribundo, por seu por seu limiar entre dois mundos, é um narrador privilegiado, pois pode falar do percurso da vida com a sabedoria do fim e anunciar o segredo da morte. Benjamin associa às crises das narrativas a negação e o afastamento da morte na modernidade.

Chama a atenção também para a relação entre a morte e a narrativa por enfatizar o esquecimento como uma produção. Na medida em que formaliza uma lembrança, narrar é produzir um esquecimento. Essa dialética entre lembrar e esquecer é o movimento da memória e das histórias contadas. Lembrar, esquecer, lembrar. O Esquecimento produz as "franjas", ornamentos no tempo.

Em Benjamin, a narrativa está atrelada ao conceito de aura, que trabalhará tanto nas considerações sobre a reprodutibilidade técnica de obras de arte como nas questões relativas a crise das narrativas tradicionais. O Narrador imprime no acontecimento sua própria vida, que passa ao ouvinte como um rastro, que o permite olhar e ser olhado, ao mesmo tempo, pela narrativa. As outras formas de comunicação modernas tem a 
intenção de relatar puramente o acontecimento, limpar justamente esse rastro de origem, no sentido benjaminiano, que transmite o estranhamento-familiar aurático.

Em "O livro por vir", Blanchot trabalha diferenças da narrativa para o romance moderno, a partir de categorias como real e acontecimento, e chama de sombra aquilo que Benjamin chama de aura: "A narrativa é o lugar da imantação, que atrai a figura real para os pontos em que ela deve se colocar, respondendo ao fascínio de sua sombra" (Blanchot, 2005: 271). A Narrativa, para Blachot, guarda em si o acontecimento, o encontro do acaso, que transmite com linguagem própria, pois a linguagem usual não dá conta dessa transmissão. Faz a ponte inevitável para a ficção como apoio para a sombra, a noite, a paixão.

\footnotetext{
Abre-se na vida de quem encontra o acaso, como que uma lacuna "verdadeiramente" uma imagem, uma lacuna imperceptível que o obriga a renunciar à luz tranquila e à linguagem usual, para manter-se sob a fascinação de uma outra claridade e em relação com a dimensão de uma outra língua. Narra-se o que não se pode relatar. Narra-se o que é demasiadamente real para não arruinar as condições da realidade comedida que é a nossa. (Blanchot, 2005: 272)
}

A narrativa guarda a metamorfose dessa passagem do real ao imaginário, que se opera no que Blanchot (2005) chama de outro tempo, diferente do cotidiano. Faz avançar de um ao outro, sendo ela mesma esse movimento de passagem: "Sempre ainda por vir, sempre já passado, sempre presente num começo tão abrupto que nos corta a respiração e, no entanto, abrindo-se como a volta e o reconhecimento eterno (...), tal é o acontecimento do qual a narrativa é a aproximação" (Blanchot, 2005: 13). Tempo transtornado pelo acontecimento, afirma o tempo próprio da narrativa, que se aloja na duração do narrador e é metamorfoseado por ele. Movimento de instauração, de temporalidades e metamorfoses, a narrativa é o próprio acontecimento, não o seu relato, por isso ela é sempre um canto de sereia, algo mais adiante, já passado, mas que logo mostrará não ser engodo.

É com a linha de engate de tempo e narrativa que Ricoeur tece um incansável e lindo trabalho, que começa com a interrogação o que é o tempo? Para Ricoeur, narrar é sempre fazer uma reconstrução temporal. Sem a narrativa, não poderíamos falar e dividir o tempo, para que exista a duração do/no tempo, a narrativa é fundamental.

Amarração entre memória, tempo e narrativa, são o mote para seu pensamento sobre a identidade, que pretende superar as durezas que compõem esse conceito. A identidade narrativa seria a forma de dar o caráter à temporalização, restituindo-lhe o 
movimento necessário a partir das intrigas-acontecimentos, que metamorfoseiam e permitem durar, diferindo. Esse autor propõe que a identidade narrativa se dá no intervalo da mesmidade, identidade-mesmo, e a ipseidade, da manutenção de si. Ela seria uma forma de produzir a variação contingente ao que está no tempo, "tornando narrável o caráter, a narrativa restitui-lhe o movimento, abolido nas disposições adquiridas, nas identificações-com sedimentadas" (Ricoeur, 1990: 171).

A questão da identidade se coloca pelo trabalho do tempo. Como dizer que é o mesmo, como dizer que é outro, na passagem do tempo? Todo trabalho da narrativa é produzir essa variação, apoiada pela personagem que vai mover-se, mover a narrativa e dar consistência ao tempo.

Fazer-se narrador de histórias de encontros de pesquisa/intervenção, colocam uma série de preocupações: a diluição do sentido na representação, a forma resistente, a forma que se dá a representar, o excesso narrativo. E também uma questão sobre o outro tornado personagem na narrativa, adquirindo roupagens próprias, a identidade narrativa, como Ricoeur conceitua em Tempo e Narrativa, e retoma no si-mesmo como um outro: "a identidade narrativa constrói a identidade do personagem, que podemos chamar de sua identidade narrativa, construindo a de história relatada. É a identidade da história que traz a identidade do personagem" (Ricoeur, 1990: 176).

Ricoeur (1990) aponta que a identidade narrativa se dá no próprio movimento de montar o si-mesmo, atividade que é de uma vida inteira e que faz a intersecção entre história e narrativa:

\footnotetext{
Elaborei então a hipótese segundo a qual a identidade narrativa, seja de uma pessoa, seja de uma comunidade, seria o lugar procurado desse cruzamento entre história e ficção. Segundo a pré-compreensão intuitiva que temos desse estado de coisas, não tomamos as vidas humanas como mais legíveis quando são interpretadas em função das histórias que as pessoas contam a seu respeito? E essas histórias de vida não são tornadas, por sua vez, mais inteligíveis quando lhes são aplicados modelos narrativos intrigas - obtidas por empréstimo à história propriamente dita ou à ficção (drama ou romance)? Pareceria, portanto, plausível considerar a cadeia seguinte de asserções: a compreensão de si é uma interpretação; a interpretação de si, por sua vez, encontra na narrativa, entre outros signos e símbolos, uma mediação privilegiada. (Ricoeur, 1990: 138)
}

A criação dessa identidade narrativa e sua duração no tempo, principalmente quando o discurso alheio é tomado como impulso-conteúdo da narrativa, no caso da produção de documentários, textuais ou audiovisuais, traz uma infinidade de questões éticas, pois ela é a construção de uma vida distante daquela da existência, recortando-a, 
restringindo-a, valorando diferente, expandindo-a.

Se a narrativa é necessária, o que parece ser, qual a forma da narrativa, ou de produção da história, que guarda esse acontecimento de que fala Blanchot, que pode fazer o tempo agir, esse tempo outro, próprio da narrativa, que invade o narrador, que lhe faz agir, que rompe as pré-figurações de eu/outro, transmitindo o acontecimento?

Eckert e Rocha (2005), ao pensar o antropólogo na figura do narrador, dão algumas pistas para pensar o tipo de encontro de que pode ser testemunho tal narrativa. Sem se resumir a uma descrição, nem uma análise introspectiva, a etnografia contempla uma certa hesitação epistemológica que lhe permite colocar

sob suspeita a condição de transparência entre as coisas ditas, vividas, faladas para e pelo antropólogo e aquelas que a sua escrita pode capturar da voz do Outro. A perfeição operatória da narrativa etnográfica depende, portanto, da capacidade de o pensamento antropológico libertar-se das percepções oriundas das situações e dos acontecimentos vividos ao longo do trabalho de campo, ou seja, a instauração da objetividade, tanto quanto da subjetividade do pensamento antropológico, reside na presença de uma "estrutura dramática" existente em qualquer pensamento humano. (Eckert e Rocha, 2005: 39)

O narrador, nessas condições, precisa esquecer de si mesmo, para acontecer o "dom da escuta". As autoras afirmam, com isso, que a etnografia é herdeira das grandes linhagens de narradores, que tinham como principal característica a transmissão da palavra do Outro:

\footnotetext{
A palavra enunciada, para sobreviver, precisa de um ouvinte. Escutar-se a palavra enunciada desdobra-se, portanto, num compromisso oculto com ela, isto é, em conservar-se coesa sua força de germinação, propagando-a no tempo. A lembrança do som da voz evoca-nos, ainda hoje, o tipo de comprometimento ético que deve pautar a entrega do antropólogo ao que lhe esteja sendo relatado assim como nosso compromisso com a perpetuação das palavras proferidas, projetando-as para além daquele que as enuncia. (Eckert e Rocha, 2005: 53)
}

Ao invés de matar o acontecimento, a narrativa é, nessa perspectiva, a criação do acontecimento. Pista já deixada por Platão, que muito temia essa maneira de "tesaurização mnêmica" que traz consigo o risco das interpretações diferentes, da democratização e até mesmo da banalização da atividade de lembrar. Escrita entendida por ele como Pharmakon, droga artificial para a memória e para a sabedoria, mas que não serve para a memória, e sim para a rememoração, ao mesmo tempo remédio que cura e veneno que traz a morte (Gagnebin, 2005).

Escrever, narrar, transmitir, seriam atos salvadores, então. Salvadores do esquecimento, salvadores da lembrança também, na dialética que é condição da 
narrativa: é reunião de elementos, mas é também atividade que apaga, renuncia, recorta, opõe ao infinito da memória, a finitude da morte - trabalho de Penélope, tecer de dia, desfazer na noite. Esquecer, lembrar, esquecer.

\begin{abstract}
A maioria guarda na memória, mas não sabe nem explicar como era. Se tiver fotografado, é mais fácil. Quando tu pega um álbum de fotografia de quando era criança e começa a folhear, aí vai lembrar melhor. E certas coisas tu vai até fazer um comentário em cima, porque está lembrando e vendo. Muitas coisas passam despercebidas, as pessoas não lembram...

As pessoas que moram aqui vão guardar na memória como era, mas as pessoas da cidade, que não conhecem, não teriam como guardar na memória... Mesmo as pessoas que moraram aqui, não iam saber Eu falo com meus guris e eles acham besteira. Eu digo pra eles que um dia vão ficar da minha idade e ter vontade de ter a lembrança de alguma coisa... É uma coisa boa. Lembranças dos velhos e tudo. E os guris dizem: "pra que guardar isso aí? Isso é velharia". Não é. Aquilo ali te lembra os pais, os avós, é a nossa história. (Tarso, 2008)
\end{abstract}

\title{
Cidade e Narrativa
}

A cidade como objeto de produção teórico-conceitual ganha importância peculiar a partir da modernidade. Paradigma do modo de pensar e viver, as cidades capitalistas são o reflexo-tempo da produção do capital. O ritmo frenético da linha de produção se espalha para as ruas, imprimindo nos corpos as gestualidades e rotinas das máquinas, que se acoplam definitivamente à subjetividade. Nasce uma forma humana metropolitana assim como se erguem as galerias e se abrem os bulevares no final do século XIX.

Simmel (1903) já buscava estabelecer os pontos de amarra onde a personalidade se acomoda na equação que estruturas como as da metrópole dispõe entre o conteúdo individual e supraindividual da vida. Segundo ele, o homem procede a diferenciações, sua a mente é estimulada pela diferença entre as impressões e a metrópole se caracteriza pela rápida convergência de imagens em mudança, a descontinuidade aguda, o inesperado de impressões súbitas. A base psicológica do tipo metropolitano se caracteriza por uma intensificação dos estímulos nervosos, que resulta na alteração brusca e ininterrupta entre estímulos interiores e exteriores. Essa hiperestimulação exige mais consciência, mais intelecto como formas de proteção da vida subjetiva contra o poder avassalador da metrópole.

O tipo Blasè, ainda segundo Simmel (1903), se caracteriza pela mescla entre a impessoalidade, imposta pela vida da metrópole, e, paradoxalmente, uma subjetividade altamente pessoalizada, com certo embotamento do poder de discriminar e reagir a novas sensações. É um tipo reservado, que tem como suporte a antipatia. 
Walter Benjamin escreveu diversos personagens literários, históricos, jornalísticos, que se reúnem na figura do Flaneur, um tipo que parece evidenciar essas características metropolitanas a partir de um certo anacronismo (que é uma intenção metodológica de Benjamin) típico das formas nascentes, um personagem que se acomoda à multidão como se mergulhado em um reservatório de eletricidade, ao mesmo tempo que faz das ruas o seu quarto. Embriagado pelo caminhar a esmo, é chamado sem cessar pela próxima esquina, o outro sorriso, o nome da rua, e cai exausto ao chegar em seu quarto, que lhe recebe com frieza. É pelo avesso que se dá a relação do flaneur entre exterior-interior, relação essa visível na cidade onde Benjamin escreve, remodelada aos novos tempos, cheia de ruínas da guerra e das tradições, adaptando-se ao novo modo de viver, como descreve essa passagem citada no seu livro das Passagens:

Os prédios de Corbusier não são nem espaçosos nem plásticos: o ar sopra através deles! O ar se torna fator constituinte! Para tal, não conta nem espaço nem plástica, apenas relação e penetração. Existe apenas um único e indivisível espaço. Caem as cascas entre exterior e interior" Sigfreid Giedidon, Bauem in Frankreich (Arquitetura na França), (Berlin, 1928: 85) (Benjamin, 1993: 194)

Esse personagem, que é também fruto do Blasè de Simmel, já que Benjamin era seu leitor, é um grande narrador da cidade, é o poeta que empresta o corpo a essa eletricidade da rua e traduz em palavras tortas essa embriaguez, mas sobrevive vendendo à industria da informação. A cidade-metrópole já nasce junto com grandes sistemas narrativos da imprensa, lógica também fragmentária e de choque, feita para a multidão e que evidencia em flash o cotidiano, categoria cada vez mais singular, apesar da vivência impessoal do caminhante na multidão: A base social da flanerie é o jornalismo. Como flaneur, o literato dirige-se ao mercado para por-se à venda. (Benjamin, 1994: 225)

A forma narrativa da imprensa trabalha os sentidos da cidade sob a égide de um grande olhar para os acontecimentos, mas é próxima dos restos e vestígios do bulevar, trabalho de rua como o do jogador, da prostituta, do homem-sanduíche, figuras capturadas pelo capitalismo, do vagar sonhador. Faz parte da imagem da cidademetrópole, que se monta em pedaços, a cada olhar, a cada esquina uma nova cena, sempre renovada no tempo, em cada olhar, essa maneira de escrever em turbilhão: 
a imprensa gera uma torrente de informações, cujo efeito estimulante é tanto mais forte quanto mais desprovidas estejam de qualquer aproveitamento. (somente a ubiquidade do leitor tornaria possível aproveitá-las; e assim se produz também a sua ilusão). (Benjamin, 1994: 225)

Do que é considerado secundário, passageiro, não-essencial, como a moda, o jogo, as vitrines, se compõe a narrativa urbana do Flaneur. O resto, os retalhos, assim como os passeios, passam a ser o material privilegiado para o estudo das humanidades, pois, sendo a cidade-metrópole prolongamento do corpo do homem contemporâneo, acompanhar esse andar que compõe a cena urbana ao mesmo tempo que se compõe, deixa de ser secundário e ganha lugar central das metodologias. Eckert e Rocha (2005) propõe que estudar:

os deslocamentos dos grupos e indivíduos entre as "províncias" e "territórios" de significação nas cidades é uma das questões cruciais para se compreender o fenômeno da memória coletiva e, por consequência, da estética urbana das modernas cidades urbano-industriais.(83).

Esse pensamento evidencia uma uma escolha por um determinado paradigma, que encontra no narrador da cidade sua expressão e aposta que há sociabilidade e compartilhamento a partir dos fragmentos das diferentes vozes, que não fazem uníssono, e que, ao se clocarem juntas não montam uma única figura. É também uma aposta na turbulência e na catástrofe como forma de compreender as sociedades humanas, e não na linearidade, o que implica uma perspectiva de cidade enquanto objeto temporal, que tem como paisagem a impressão das várias temporalidades presentes nos movimentos de seus habitantes (Eckert e Rocha, 2005: 86-87).

Essa forma interpretativa, faz protagonistas os itinerários dos habitantes, instaurando-os como formadores dos espaços habitados na cidade e não simples efeitos de políticas públicas e privadas.

A cidade ressurge enquanto manifestações expressivas dos gestos humanos que lhe fazem ascender a status legítimo de "espaço habitado", graças a sua autonomia absoluta como espaço poético, repleto das imagens e histórias a elas atribuídas. Em decorrência, os espaços urbanos construídos e vividos, como objeto etnográfico, vão se revelando não como meros reflexos de políticas urbanísticas, mas como suportes de tradições e biografias de seus habitantes cujas narrativas expressam uma linguagem coletiva que comunica uma pluralidade de identidades e memórias, remetendo seus territórios aos pretextos e às manipulações humanas." (Eckert e Rocha, 2005: 87)

A interpretação restitui, assim, certa dimensão de vestígio e de aura, categorias que compõe a figura do Flaneur e são alvo metodológico de Benjamin em seu trabalho 
das Passagens. Ao banalizar o espaço, o poeta o faz singular e próprio de cada habitante, ainda que pregnado e pregnante de toda a política institucional. É performático da racionalidade estética metropolitana, e produz a partir torções/atualizações: é todo ele entremeado por citações das transformações no transporte coletivo, que é uma imagem do próprio conceito de coletivo, que é uma imagem presente na arquitetura que está rompendo, na época, conceitos de exterior/interior. Imagens sobrepostas que formam uma constelação de época e que encontra-se com imagens contemporâneas no movimento de tensionamento que é seu método.

As imagens-pensamento benjaminianas são históricas, mas transmitem, por justaposição e descontextualização originária ${ }^{7}$, as tensões possíveis de se encontrar sem resolução nesses flaches da cidade-metrópole nascente no início do século XX. O método de colagem, que forma um quadro precário a partir de fragmentos, talvez seja um horizonte possível para a cidade contemporânea diante do esfacelamento produzido pela capitalização devastadora do espaço público.

\section{As Narrativas em queda e as Narrativas difíceis (por que as narrativas difíceis?)}

Já se tornou corrente uma discussão em torno da questão das narrativas, e suas dificuldades a partir da modernidade. Lyotard (1986) trabalha essa questão propondo que o caráter credível das grandes narrativas (mitos, fábulas e as metanarrativas modernas), legitimantes das instituições, das práticas sociais, de uma ética e de maneiras de pensar, teria se exaurido com a não concretização do projeto moderno. Segundo ele, o não-acabamento que marca a modernidade, não veio a ser por que foi destruído, depois de alguns acontecimentos, dentre eles destaca Auschwitz. A pósmodernidade teria nascido de um assassinato, assassinato da categoria "povo", legitimante das práticas modernas:

Isso não quer dizer que já não haja narrativas credíveis. Por metanarrativa, ou grande narrativa, entendo precisamente narrativas com uma função legitimante. $\mathrm{O}$ seu declínio não impede que milhares de histórias, umas pequenas e outras menos, continuem a ser a trama da vida cotidiana. (Lyotard, 1986: 33)

Também Walter Benjamin (1993) escreveu sobre a queda da condição de narratividade a partir da modernidade, junto com o fim da narração tradicional. Em

\footnotetext{
${ }^{7}$ Alusão a sua peculiar idéia de origem como salto para fora da linha do tempo, cesura da história, "turbilhão no rio do devir" (Benjamin, 1984).
} 
"Experiência e Pobreza" $(1933,1993)$ traz a figura emblemática do narrador tradicional, que, referido a uma temporalidade comum a várias gerações, conta uma história para ser seguido, e não somente escutado. A Experiência supõe esse compartilhamento e traz consigo uma formação que é válida para todos de uma mesma coletividade. Também em “O Narrador” (1936, 1993), retoma a problemática da experiência e das diferenças relativas ao fim das grandes narrativas, mas recupera um caráter atemporal da figura do narrador, que dá pistas para uma atividade que faria a reunião de elementos do passado, sem no entanto recair nas narrativas sobre as quais pensa Lyotard. Sobre "O Narrador" escreve Gagnebin:

\footnotetext{
Não se trata tanto de deplorar o fim de uma época e de suas formas de comunicação quanto de detectar na antiga personagem, hoje desaparecida, do narrador, uma tarefa sempre atual: a de apokatastasis, esta reunião de todas as almas do Paraíso, segundo a doutrina (condenada por heresia) de Orígenes, uma doutrina que teria influenciado Lesskov. Recolhimento que a figura do narrador, essa figura secularizada do justo, efetuaria por suas narrativas, mas, singularmente, que definirá também o esforço do "historiador materialista", tal como o chama Benjamin nas "Teses". (Gagnebin, 1999: 62)
}

A oposição à atividade salvadora do passado não seria a falta de tradições compartilhadas, mas a realidade de um sofrimento tão grande que não é comunicável. A primeira guerra revelou essa experiência de emudecimento da humanidade, que os romances de guerra não deram conta de sanar. O Narrador não é um lamento de Benjamin em relação ao fim da tradição, mas uma questão sobre a narração, sobre qual forma narrativa poderia dar conta desses emudecimentos, silenciamentos da história, de forma a preservar o que passado tem de irredutível, inacabado, e que respeita a imprevisibilidade do presente (Gagnebin, 1999).

Essa história emudecida por excesso precisa de um suporte narrativo para passar adiante, ser transmitida. A literalidade é o próprio excesso, ela precisa de metáforas, de algo pelo qual pode ser substituída. Mas como representar algo que está além de nossa capacidade de imaginar? (Seligman-Silva, 2000: 112). A narrativa, nessa perspectiva do sobrevivente da catástrofe, "combina memória e esquecimento. Primo Levi afirma que não sabe se os testemunhos são feitos "por uma espécie de obrigação moral com os emudecidos ou, então, para nos livrarmos de sua memória”," (Seligman-Silva, 1999: 42).

Há alguns traços frequentes nos relatos de sobreviventes de guerra que apresentam essa irredutível condição de tensão entre um evento absolutamente singular 
e impossível de universalizar (pois não há forma de representação possível) e a condição da linguagem, que funciona a partir de universais e o singular é frequentemente abandonado. Dessa tensão resta, sobra o que resiste ao revestimento do discurso, e que aparece na literalização da linguagem-forma de contar e também na fragmentação do discurso. Para além dos relatos de sobrevevintes, a Shoah acabou por instaurar um dilema entre ralidade e ficção, e trouxe o teor testemunhal e a questão sobre a experiência e sua transmissão para a ordem do dia em boa parte da produção artística e cultural.

A vivência do campo de concentração e a existência desse fato para a história coloca outro ponto da crise da narrativa, apontada por Benjamin, que é a distância da morte do cotidiano da humanidade a partir da modernidade. Para Márcio SeligmanSilva (2000), a Shoah operou um perfuramento do campo da morte por sua onipresença. Deixou de ser assim o organizador simbólico, separador de águas, litoral de mundos. A "morte da morte" seria o devastador resultado dessa catástrofe.

Seligman-Silva (1999) considera que a literatura de testemunho traz de volta a morte ao seu lugar de organizador da linguagem: Se o indizível está na base da língua, o sobrevivente é aquele que reencena a criação da língua" (41). Tem o dever de dizer para não esquecer da morte como figura limite da história, para quem sabe esquecer e lembrar.

Guardadas as dimensões de distância temporal e cultural da Shoah, vive-se a suspensão de direitos em diversas ruelas da cidade, onde é possível matar e morrer sem isso seja considerado crime. Quando se experimenta o radical limiar do "fora da lei", das habitações e práticas sociais não legitimadas, uma certa permissividade em relação a esse limite maior, que é a morte, se faz cotidiano e o Estado se mostra com perversidade.

Os personagens das histórias que movem essa reflexão enfrentam esses limites diariamente e a dificuldade em contar histórias obedece a esse transbordamento. As histórias aparecem em fragmentos isolados, com tamanha variação que parecem não caber na mesma narrativa. Família, prole, espaço, nada se fixa. Tudo está em movimento veloz, sem que um projeto possa se delinear em prática, sem que uma conta feita no Big possa assegurar o dia de amanhã ${ }^{8}$.

\footnotetext{
${ }^{8}$ Lembro também da personagem do documentário de Eduardo Coutinho, Edifício Master (2002) que foi salva de se atirar da janela do 20 andar pelo carnê a pagar ao Ponto Frio, não queria morrer deixando dívidas. E também à dona Lena, que teve seu aparelho de som levado pela enchente, depois de pagar a
} 
Ricoeur (1990), quando se concentra em examinar a problemática da identidade, toca no tema nos limites de não-narratividade da identidade pessoal. Já foi apresentada a dialética essencial da identidade, onde a identidade narrativa é o que faz a mediação entre a ipseidade, que seria a manutenção de si, "a palavra considerada", como refere esse autor, e a mesmidade, ou identidade-idem, que seria o caráter. Uma depende da outra quando se coloca em questão a duração no tempo e o que faz essa ligação movente é a identidade narrativa. Ela se compõe, portanto de variações, variações imaginativas, na dialética que ela produz e procura. Ao mesmo tempo, uma esperança em nas disposições duráveis, do caráter que se reafirma, e na palavra que se cumpra. Situa na literatura diversos exemplos de como perceber essas variações, que nos personagens de contos de fadas e do folclore predomina a reidentificação do mesmo, do caráter identificável que se afirma a partir das intrigas, enquanto no romance moderno, a pesar de diferir de autor para autor, essa balança inverte, e a identificação do mesmo decresce, na maioria das vezes sem desaparecer.

Mas situa alguns movimentos em que vai alcançar um limiar, em que o personagem é a pura variação, sem o apoio das disposições duráveis do caráter. Nas ficções de perda de identidade percebe um limite de narratividade, e cita como exemplar "O homem sem Qualidades" de Musil, um mundo de qualidades sem homens: "A perda de identidade do personagem corresponde, assim, à perda de configuração da narrativa e, em particular, uma crise da conclusão da narrativa." (Ricoeur, 1990: 177). Sem o apoio da mesmidade, como se faz a manunteção de si?

Criação reativa a essa crise, as narrativas de ficções científica, fazem variante a própria mesmidade. Retiram dos personagens, para isso, a dimensão corporal que produz um traço próprio de ipseidade, uma vez que ela é uma mediação existencial entre o si e o mundo. Com o sonho tecnológico que é a fonte dessas narrativas, o cérebro se torna o equivalente da pessoa, e as operações relativas a identidade se dão nesse plano. Uma vontade compartilhada nesse sonho de se desvencilhar de todos os constrangimentos da existência corpórea, traz uma identificação inevitável com os personagens da ficção, com seu sofrimento, pois é o corpo e suas bordas que nos coloca todos na condição “terrestre”, escreve Ricoeur, no sentido de lugar mítico, ancoradouro de nosso corpo no mundo.

Os movimentos de variação imaginativa mais comuns entre os personagens da

última prestação no Big. 
ficção literária são no sentido da ipseidade e sua relação dialética com a mesmidade. Aponta, no entanto, que no caso das narrativas de perda de identidade essa dialética se rompe.

\begin{abstract}
Minha tese é que, recolocando no quadro do idem e do ipse, esses casos desconcertantes da narração se deixam reinterpretar como desguarnecidos da ipseidade por nada de suporte da mesmidade. É nesse sentido que eles constituem o polo oposto ao do herói identificável por superposição da ipseidade e da mesmidade. O que se perdeu agora, sob o título de "propriedade", é o que permitia igualar o personagem a seu caráter. (Ricoeur, 1990: 175)
\end{abstract}

A reunião dos elementos que configura a narrativa é sempre um trabalho de coautoria de sentido e quando os personagens não tem muito suporte de mesmidade, há um risco de tentar produzir essas disposições duráveis nas histórias escutadas. Há possibilidade de tentar produzir esses heróis dos contos, sob a roupa dos "excluídos", dos sem, das prefigurações todas que essas existências na margem já receberam. Há também possibilidade da literalidade, de registrar e transcrever simplesmente, pela dificuldade em tomar um fio de meada em algumas histórias.

E há também a possibilidade de se deixar levar por elas, que são cheias de penhascos, de vãos estreitos, de enxurradas, de aberturas de asfalto, de pedregulhos e telhados de lata, de incêndios e separações, e produzir na escrita o acontecimento. $\mathrm{Ou}$ seja, deixar viver na narrativa essas várias camadas que não se compõem, que tem uma existência paralela e não de continuidade. O herói que falha, que mente, que erra. A literalidade que é uma ponta do real, poética. O labirinto que torce a história em linha reta. A cidade que falseia a cidade. Essa potência ${ }^{9}$ da narrativa, que não está preocupada em produzir uma verdade, talvez se aproxime mais dos territórios-subjetividades em transformação, e aí faça as vezes de transmissão, várias camadas de histórias, possíveis para várias camadas de interlocutores.

\title{
Referências
}

BENJAMIN, Walter. Origem do drama barroco Alemão. São Paulo: Brasiliense, 1984. . Magia e técnica, arte e política. Obras Escolhidas, vol. I. São Paulo: Brasiliense, 1993.

- Charles Baudelaire um lírico no auge do capitalismo. Obras escolhidas vol. III. São Paulo: Brasiliense, 1994.

\footnotetext{
${ }^{9}$ É possível ler em Deleuze como "potência do falso" no livro: DELEUZE, Gilles. A Imagem-Tempo. Cinema 2. São Paulo: Editora Brasiliense, 1990.
} 
BLANCHOT, Maurice. O livro Por Vir. São paulo: Martins Fontes, 2005.

CANEVACCI, Massimo. A cidade Polifônica - ensaio sobre a antropologia da comunicação urbana. São Paulo: Studio Nobel, 2004.

DIDI-HUBERMAN, G. O que vemos, o que nos olha. São Paulo: Ed. 34, 1998.

GAGNEBIN, Jeanne Marie. História e narração em Walter Benjamin. São Paulo: Perspectiva, 1994.

Imago, 2005.

Sete Aulas sobre linguagem, memória e história. Rio de Janeiro:

ECKERT, Cornelia e ROCHA, Ana Luiza Carvalho da. "O antropólogo na figura do narrador”. In: O tempo e a cidade. Porto Alegre: Ed. UFRGS, 2005. p. 33-56.

ECKERT, Cornelia e ROCHA, Ana Luiza Carvalho da. "A cidade como objeto temporal". In: O tempo e a cidade. Porto Alegre: Ed. UFRGS, 2005. p. 79-100.

GUATTARI, F. Caosmose: um novo paradigma estético. Rio de Janeiro: Editora 34, 1992.

HUYSSEN, Andreas. Seduzidos pela Memória: arquitetura, monumentos, mídia. $2^{\mathrm{a}}$ Ed. Rio de Janeiro: Aeroplano, 2000.

NESTROVSKI, A.; SELIGMANN-SILVA, M. Catástrofe e Representação. São Paulo: Escuta, 2000.

PELBART, Peter Pál. Vida Capital- Ensaios de biopolítica. São Paulo: Iluminuras, 2003.

POLLACK, Michael. "Memória, esquecimento, silencio”. In: Estudos Históricos, v. 2, n. 3. Rio de Janeiro: CPDOC/FGV, 1989. p 3-15.

RICOEUR, Paul. $O$ si e a identidade narrativa. $O$ si-mesmo como um outro. Campinas: Papirus, 1991.

SELIGMANN-SILVA, Márcio. "A literatura do trauma". In: Revista Brasileira de Literatura, n. 23. São Paulo: Lemos Editorial, 1999. p. 40-47.

SIMMEL, G. "A metrópole e a vida mental”. In: VELHO, Otávio G. (org). O fenômeno urbano. Rio de Janeiro: Zahar, 1979. p 11-25.

Recebido em: 21/12/2010

Aprovado em: 28/03/2011 